\title{
Effect of the microenvironment and embryo density on developmental characteristics and gene expression profile of bovine preimplantative embryos cultured in vitro
}

\author{
Michael Hoelker, Franka Rings, Qamaruddin Lund, Nasser Ghanem, Chirawath Phatsara, \\ Josef Griese, Karl Schellander and Dawit Tesfaye
}

Animal Breeding and Husbandry Group, Insititute of Animal Science, University of Bonn, Endenicher Allee 15, 53115 Bonn, Germany

Correspondence should be addressed to M Hoelker; Email: michael.hoelker@itz.uni-bonn.de

\begin{abstract}
The Well of the Well (WOW) system has been developed to culture embryos in small groups or to track the development of single embryos. In the present study, we aimed to examine the effects of the microenvironment provided by the WOW system and embryo density on developmental rates, embryo quality and preimplantative gene expression profile of the resulting embryos. Embryos cultured in a group of 16 reached the blastocyst stage at a significantly lower level than zygotes cultured in a group of 50 (22.2 vs $30.3 \%)$, whereas zygotes cultured in WOW were able to compensate against low embryo densities, reaching a blastocyst rate as high as embryos cultured in a group of 50 (31.3 vs $30.3 \%)$. Moreover, embryos derived from WOW culture did not differ in terms of differential cell counts and apoptotic cell index compared with controls. The gene expression analysis revealed 62 transcripts to be upregulated and 33 transcripts to be downregulated by WOW culture. Comparing the in vivo derived blastocysts with the blastocysts derived from WOW culture, and group culture, expression of ATP5A1, PLAC8 and KRT8 was more similar to the embryos derived from WOW culture, whereas expression of S100A10 and ZP3 genes was more similar to blastocysts cultured in a group. In conclusion, microenvironment as well as embryo density significantly affected developmental rates. While subsequent blastocysts did not differ in terms of differential cell counts and apoptotic cell index, significant differences were observed in terms of the relative abundance of transcripts in the resulting embryos.

Reproduction (2009) 137 415-425
\end{abstract}

\section{Introduction}

The preimplantation mammalian embryo is relatively autonomous and can regulate cell cleavage and differentiation without being in contact with the maternal reproductive tract (Schultz \& Heyner 1993). In vivo, it is exposed to numerous factors that are absent in vitro and which mediate the maternal-embryonic dialogue (Paria \& Dey 1990, Hill 2001). This could partly be responsible for the impaired in vitro development and viability of in vitro cultured preimplantation embryos (Harlow \& Quinn 1982). Moreover, in vitro derived embryos show altered gene expression (Wrenzycki et al. 1998, 2001, Niemann \& Wrenzycki 2000) as well as increased rates of apoptosis (Brison \& Schultz 1997).

Nevertheless, a number of previous investigations proved that in vitro culture of mammalian embryos may be remarkably successful when the embryos are kept in large groups during the whole culture period (Paria \& Dey 1990, Ferry et al. 1994). However, apart from the large-scale production of embryos for experimental purposes, most commercial and human embryo culture systems require culturing individually or in small groups. The reason for this need is the small number of available oocytes (ovum pick-up (OPU) technology, single slaughtered valuable oocyte donors, human IVF) as well as only single embryo culture allows tracking individual embryos throughout the whole culture period (Moessner \& Dodson 1995).

Therefore, several techniques for single IVP systems have been developed (Lane \& Gardner 1992, Kato \& Tsunoda 1994, Blondin \& Sirard 1995, Hazeleger et al. 1995, Carolan et al. 1996, O'Doherty et al. 1997). However, if single embryo culture is associated with a low embryo density (embryo number: medium volume ratio), the development in this situation is handicapped indicated by low blastocyst rates, low cell numbers and decreased production of interferon- $\tau$ (O'Doherty et al. 1997, Larson \& Kubisch 1999, Khurana \& Niemann 2000). Thus, embryo density that determines the interaction of embryonic factors in the microenvironment seems to be an important factor for the effectiveness of bovine vitro culture (Fujita et al. 2006, Nagao et al. 2008). 
Due to that the most commonly used method when culturing few embryos to decrease the embryo/volume rates is to place the embryos in small droplets (Fujita et al. 2006, Nagao et al. 2008). Ferry et al. (1994) observed the best embryonic development of bovine embryos to the blastocyst stage $(18 \%)$ at a density of $1: 1$ (embryos: volume culture medium). When culturing embryos in a density of $1: 10$, the same authors reached a blastocyst rate of $2.5 \%$. Fujita et al. (2006) identified an embryo density of 1:5 to be most beneficial; however, the culture of single bovine embryos to the blastocyst stage in droplets of $5 \mu \mathrm{l}$ failed (Ferry et al. 1994). Therefore, individual culture of bovine embryos in droplets is harmful because of a low embryo density or leads to low developmental rates due to small total volumes. Culturing embryos in small droplets may lead to an accumulation of toxic substances such as ammonia (Gardner \& Lane 1993, Sinclair et al. 1998) and oxygenderived radicals (Johnson \& Nasr-Esfahani 1994), which may be harmful for embryos or are suggested to lead to late developmental anomalies. Medium changes every $48 \mathrm{~h}$ could theoretically compensate against this toxic accumulation, but this manipulation may have harmful effect on embryo development (Fukui et al. 1996) and would lead to an elimination of positive acting autoand paracrine factors too.

To overcome these problems, the Well of the Well (WOW) culture system has been developed previously (Vajta et al. 2000). WOWs (semi-isolated microenvironments with $0.15-0.04 \mu \mathrm{l}$ ) on the bottom of a conventional four well dish provide a constant and suitable microenvironment for embryos and the open condition of the WOW system seems to be a good compromise between the controversial needs of large (nutrition and dilution of metabolized toxic products) and small (accumulation of autocrine and paracrine factors) volumes. Most recently, the WOW system has been used to culture human preimplantative embryos up to the blastocyst stage (Vajta et al. 2008). Comparative studies on the effects of various embryo densities have generally focused on the percentage of embryos that proceed to the blastocyst or hatched blastocyst stages (Ferry et al. 1994, Fujita et al. 2006). While it is reasonable to use such developmental end points as markers of the efficiency of culture systems, other groups have analysed morphological aspects like differential cell counts (Hoelker et al. 2006) or apoptotic cell index (Fouladi-Nashta et al. 2005). Nevertheless, new parameters to determine bovine embryo quality are necessary. Although lots of studies have dealt with differences in gene expression pattern between in vivo derived bovine embryos associated with high quality and in vitro derived embryos associated with poor quality, only few have been reported about the effects of varying embryo densities on bovine preimplantative gene expression. To our knowledge, only de Oliveira et al. (2005) reported the effect of different embryo densities on transcript expression of certain genes. The relative abundance of HSPA1A transcripts in day-7 blastocysts was found to be higher in embryos produced in embryo densities of 1:5 than in 1:20, whereas no difference in terms of SLC2A1 mRNA was observed. Moreover, studies examining the pattern of expression of important genes as a function of embryo culture in WOWs are still lacking. Although some pregnancies have been achieved after the transfer of human embryos derived from WOW culture (Vajta et al. 2008), it is still unresolved whether the gene expression pattern of embryos culture in WOWs is affected by microenvironment and/or embryo density.

Therefore, in this study, we aimed to examine both the effect of the microenvironment provided by the WOW and different embryo densities on embryo quality. To gain as much information as possible, we analysed the effects of WOW culture and embryo density on developmental rates, embryo quality in terms of differential cell count and apoptotic cell index as well as the gene expression profile of the resulting bovine embryos.

\section{Results}

\section{Experiment 1. Effect of microenvironment on in vitro developmental characteristics of bovine zygotes}

Zygotes cultured within WOWs $(n=176)$ showed no difference in terms of cleavage rate compared with embryos cultured in a group of 16 or a group of 50 . By contrast, embryos cultured in a group of 16 reached the blastocyst stage at a significantly lower rate than zygotes cultured in the group of 50 (22.2 vs $30.3 \%)$, whereas zygotes cultured in WOWs reached a developmental rate to the blastocyst stage not different from group of 50 control group (31.3 vs $30.3 \%$ ), but being significantly superior compared with embryos cultured in the group of 16 culture system (29.0 vs $22.2 \%$ ) as shown in Table 1 .

Moreover, blastocysts derived from culture in WOWs did not exhibit differences with blastocysts derived from

Table 1 Effect of Well of the Well (WOW) 16 culture system on differential cell counts of developed bovine blastocysts.

\begin{tabular}{lcllrr}
\hline & & & & \multicolumn{2}{c}{ Cell counts } \\
\cline { 4 - 6 } Culture system & Zygotes $(n)$ & Cleaved $n(\%)$ & Blastocyst $n(\%)$ & Total & TE \\
WOW 16 & 176 & $135(76.7)$ & $55(31.3)^{\mathrm{b}}$ & 99.6 & 68.6 \\
Group of 16 & 176 & $139(79.0)$ & $39(22.2)^{\mathrm{a}}$ & 99.3 & 31.0 \\
Group of 50 & 274 & $218(79.6)$ & $83(30.3)^{\mathrm{b}}$ & 105.0 & 31.8 \\
\hline
\end{tabular}

Values with different superscripts within columns differ significantly $\left.{ }^{\text {a:b }} P<0.05\right)$. 
group of 16 or 50 culture system in terms of differential cell counts (Table 1), and blastocysts derived from WOW 16 culture system exhibited no differences in term of apoptotic cells index compared with blastocysts cultured in a group of 16 or a group of 50 (Table 2).

\section{Experiment 2. Effect of microenvironment on embryonic gene expression profile}

When bovine blastocysts derived from both WOW 16 culture and group of 16 culture were produced for gene expression studies, the developmental rates differed significantly and confirmed the results of experiment 1 . Embryos cultured in WOW 16 reached a blastocyst rate of $32.7 \%$ (122 out of 384 ) and embryos cultured in group of 16 reached a blastocyst rate of $21.0 \%$ (124 out of 591). Blastocysts developed in the WOW 16 culture system showed a different gene expression pattern than blastocysts cultured in a group of 16. Significance analysis of microarray (SAM) identified 95 transcripts differentially regulated compared with blastocysts derived from group of 16 culture. A total of 62 transcripts were found to be upregulated (Fig. 1) and 33 transcripts were found to be downregulated (Fig. 2) by WOW culture compared with group culture. Up- and downregulated genes were grouped based on their molecular functions and biological processes considering the criteria of gene ontology consortium classifications (http://www.geneontology.org). Blastocysts derived from WOW 16 culture system were found to be enriched with genes regulating different molecular functions (Fig. 3) including structural constituent of ribosome (RPS29), protein binding (CUL1), calcium ion binding (S100A10, NPTX2), nitric-oxide synthase regulator activity (HSP90AA2) and RNA polymerase II transcription factor activity (UHRF1). However, control blastocysts derived from group of 16 culture system were found to be enriched with genes involved in oxidoreductase activity $(A L O X 15, A K R 1 B)$, cytochrome-c oxidase activity (COX7A2), hydrogen ion transporting ATP synthase activity (ATP5O), transcription (PTTG1), cell redox homeostasis $(T X N)$. According to their biological process, genes enriched in blastocysts derived from WOW 16 culture system belong to 'small molecule transport' and 'signal transduction' whereas certain genes downregulated in blastocysts

Table 2 Effect of Well of the Well (WOW) 16 culture system on apoptotic cell index of developed bovine blastocysts.

\begin{tabular}{lcccc}
\hline & & \multicolumn{3}{c}{ Cell counts } \\
\cline { 3 - 5 } Culture & & & & \\
system & Total blastocysts & Total cells & Apoptotic cells \\
\hline WOW 16 & 48 & 118.68 & 3.31 & $2.8 \%$ \\
Group of 16 & 42 & 129.82 & 3.33 & $2.6 \%$ \\
Group of 50 & 43 & 144.83 & 2.79 & $1.9 \%$ \\
\hline
\end{tabular}

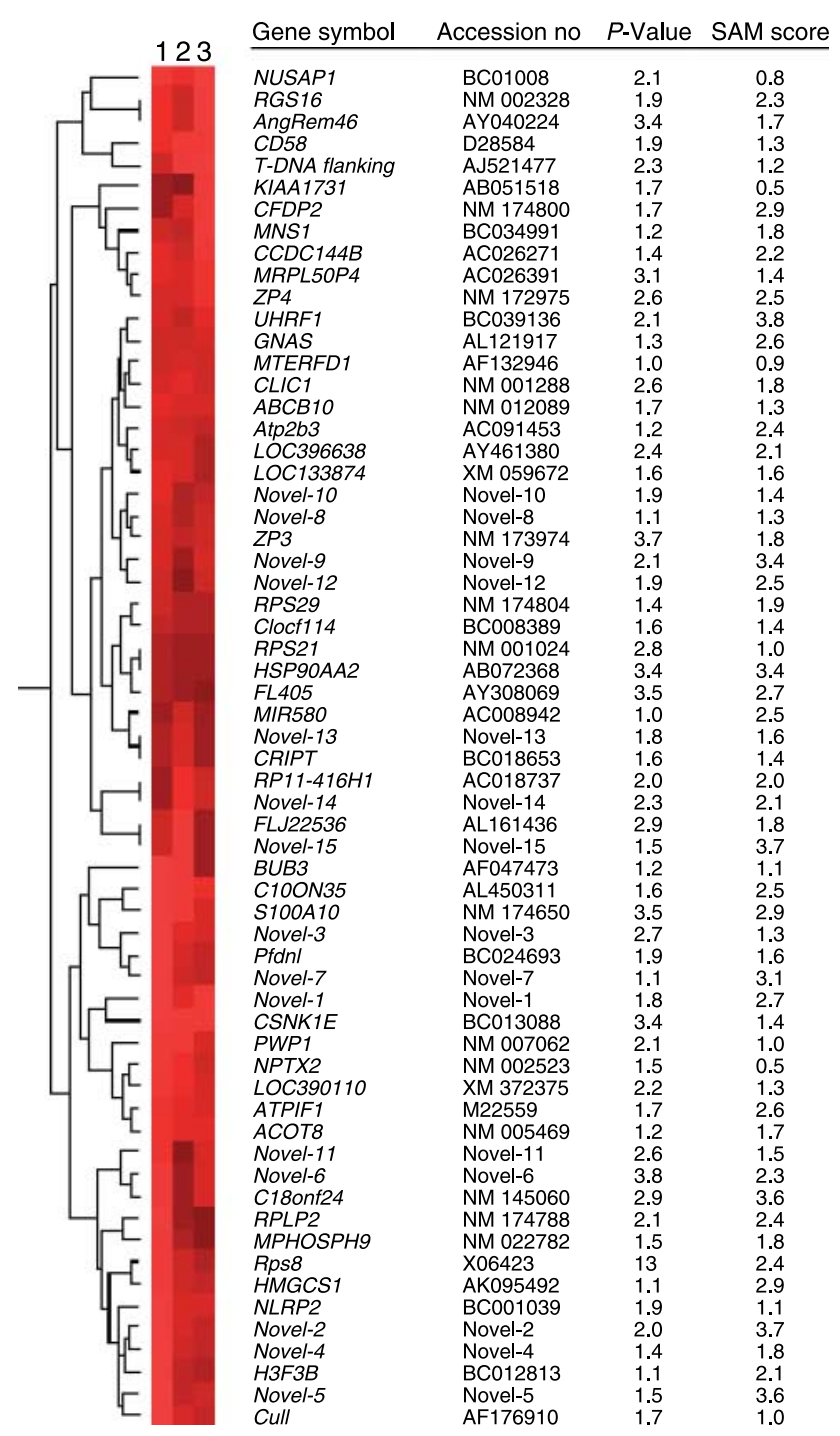

Figure 1 Hierarchical clustering of transcripts upregulated in WOW 16 culture compared with group of 16 culture.

derived from WOW 16 culture system have a metabolic function (Fig. 4).

\section{Experiment 3. Comparison of in vivo derived bovine blastocysts with ones derived from different in vitro culture systems in terms of gene expression}

Real-time PCR analysis of ATP5A1, PLAC8, KRT8, S100A10 and ZP3 genes between blastocysts derived from the WOW 16 culture system, group of 16 , group of 50 and in vivo-derived embryos culture showed that the relative abundance was confirmed. In any case, the relative abundance was significantly higher for blastocysts derived from in vitro culture compared with blastocysts derived from in vivo flushings (gold standard). For the genes ATP5A1, PLAC8 and KRT8, the relative abundance of these transcripts was higher in blastocysts derived from group of 16 culture compared 


\begin{tabular}{|c|c|c|c|c|c|}
\hline & Gene symbol & Accession no & $P$-Value & SAM score \\
\hline & & $H 2 A F Z$ & X52318 & 1.0 & 0.0 \\
\hline & & PTTG1 & NM 004219 & 2.5 & 1.1 \\
\hline & & PGHS-2 & AF031698 & 1.3 & 0.3 \\
\hline & & $R a b-G D P D I 2$ & AF095729 & 1.5 & 2.7 \\
\hline & & Novel-20 & Novel-20 & 2.9 & 0.8 \\
\hline & & Degs1 & BC003751 & 2.0 & 1.0 \\
\hline & & COX7A2 & NM 175807 & 2.3 & 0.6 \\
\hline & & KRTS & X12877 & 3.5 & 1.3 \\
\hline & & NDUFA7 & NM 176658 & 2.4 & 2.4 \\
\hline & & ORCA13962 & AB099150 & 1.1 & 1.1 \\
\hline & & TPX2 & BC020207 & 1.3 & 1.3 \\
\hline & & CH240-454H24 & AC150492 & 1.1 & 2.1 \\
\hline & & NPM2 & AY 262114 & 1.6 & 0.6 \\
\hline & & LGALS1 & AB099039 & 2.2 & 1.8 \\
\hline & & $B 2 M$ & AY325771 & 2.0 & 3.6 \\
\hline & & Novel-16 & Novel-16 & 2.3 & 0.9 \\
\hline & & LAPTM $4 A$ & NM 205799 & 1.2 & 2.4 \\
\hline & & H2AFZ & NM 174809 & 1.7 & 1.3 \\
\hline & & AKR1B1 & M31463 & 1.4 & 2.1 \\
\hline & & $B 2 M$ & AB098926 & 1.5 & 0.6 \\
\hline & & PLAC8 & NM 016619 & 3.1 & 1.9 \\
\hline & & $T X N$ & AF104105 & 2.6 & 1.3 \\
\hline & & ACTB & AY141970 & 1.1 & 1.5 \\
\hline & & ATP5O & NM 174244 & 3.7 & 2.2 \\
\hline & & RPL 18A & AB098916 & 2.4 & 1.8 \\
\hline & & RPS 15 & NM 001018 & 2.8 & 1.3 \\
\hline & & TKDP1 & AF241776 & 1.3 & 2.5 \\
\hline & & GDPD5 & AP002815 & 1.9 & 2.1 \\
\hline & & $F H$ & BC017444 & 2.0 & 1.4 \\
\hline & & ALOX15 & NM 174501 & 3.7 & 2.9 \\
\hline & & Novel-19 & Novel-19 & 0.0 & 1.7 \\
\hline & & Novel-18 & Novel-18 & 2.1 & 3.6 \\
\hline & & Novel-17 & Novel-17 & 3.5 & 0.9 \\
\hline
\end{tabular}

Figure 2 Hierarchical clustering of transcripts downregulated in WOW 16 culture compared with group of 16 culture.

with that of blastocysts derived from the WOW 16 culture system (Fig. 5A-C). For these genes, expression was higher in blastocysts derived from group of 50 culture compared with those derived from group of 16 culture. The expression of S100A10 and ZP3 was not different between blastocysts derived from group of 50 culture and group of 16 culture but was significantly lower compared with blastocysts derived from the WOW 16 culture system $(P<0.05)$ as shown in Fig. 5. For both genes, the transcript amount was lowest in blastocysts derived from in vivo flushings at day 7.

\section{Discussion}

In this study, we were able to compare the differences in development, differentiation, apoptosis and gene expression for embryos cultured in different microenvironments as well as the effect of embryo density in terms of development, differentiation, apoptosis and expression of ATP5A1, KRT8, PLAC8, S100A10 and ZP3 genes.

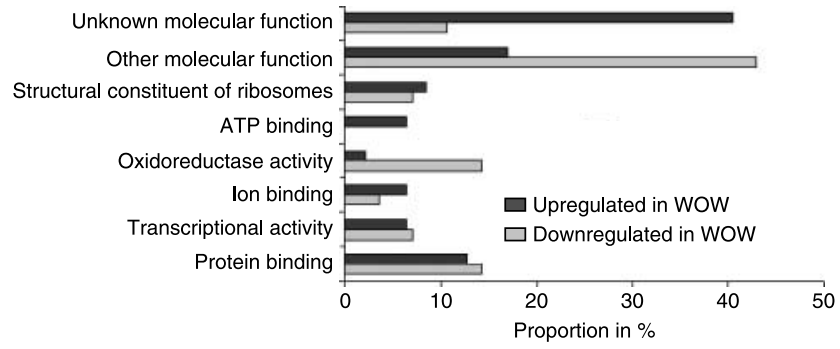

Figure 3 Relative grouping of genes up- and downregulated in blastocysts derived from WOW 16 culture system in accordance to their molecular function.

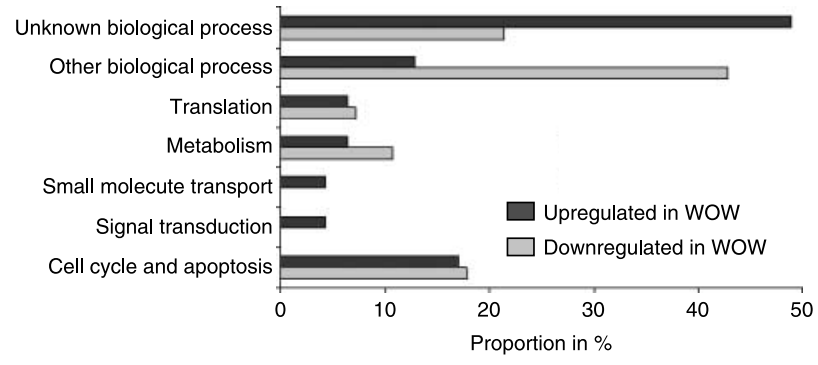

Figure 4 Relative grouping of genes up- and downregulated in blastocysts derived from WOW 16 culture system in accordance to their biological process.

As a result, embryos cultured in a group of 16 showed lower development to the blastocyst stage than embryos cultured in a group of 50 . The difference between these treatments is an embryo density of 1:32 for the culture in group of 16 and 1:10 for group of 50 culture. This is in agreement with the previous reports that showed that embryo density is an important factor in bovine (Ferry et al. 1994, Palasz \& Thundathil 1998, Fujita et al. 2006, Nagao et al. 2008), pigs (Taka et al. 2005) and mice (Kato \& Tsunoda 1994, Thouas et al. 2003). Ferry et al. (1994) reported the best embryonic development of bovine embryos to the blastocyst stage (18\%) at an embryo density of 1:1 (embryos: volume culture medium) whereas Fujita et al. (2006) identified an embryo density
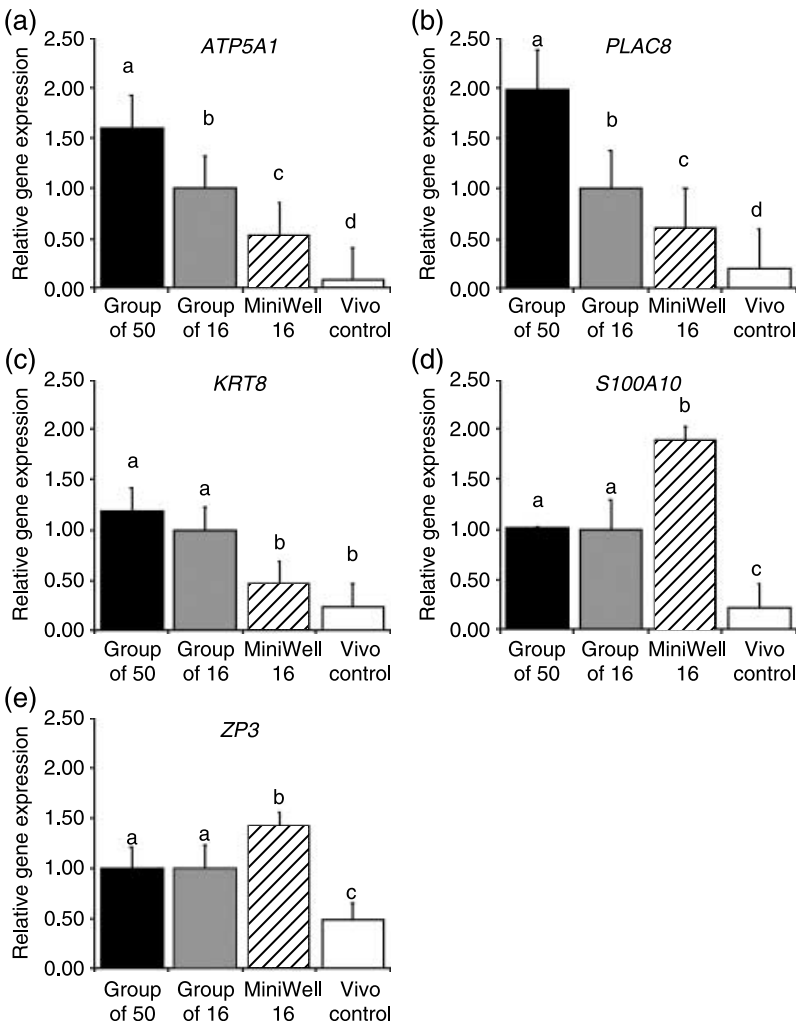

Figure 5 Comparison of in vivo-flushed bovine blastocysts with those derived from different in vitro culture systems in terms of gene expression. ${ }^{\mathrm{a}-\mathrm{d}}$ Different superscripts indicate significant differences $(P<0.05)$. 
of $1: 5$ to be most beneficial. Compared with these studies, embryo density was relatively low $(1: 32)$ in our experiments when cultured in group of 16 or WOW 16 . However, these studies cannot be compared directly with our study, because in these experiments drop culture was used whereas we cultured in dishes.

When we cultured 16 embryos each single in one WOW in the same embryo density (1:32) as we did in the group of 16 culture, WOWs significantly improved the developmental potential to the blastocyst stage comparable with embryos cultured in an embryo density of 1:10 (group of 50). This result is in accordance with the recent reports showing that the blastocyst rate was improved by the WOW system (Vajta et al. 2000, Taka et al. 2005). The microenvironment created by the WOWs might allow a suitable concentration of embryonic factors surrounding embryos to be maintained, which compensates against lower embryo numbers in the total culture volume. Also, the open condition of the WOW culture system may diffuse toxic substances originating in embryo metabolism.

Embryos cultured in WOWs did not differ in terms of differential cell counts and apoptotic cell index compared with controls. That is in accordance with the previous reports, which showed no difference in differential cell counts both for bovine (Vajta et al. 2000) and porcine embryos (Taka et al. 2005) cultured in the WOW system compared with embryos cultured in groups. Contrarily, a large-scale change of the global gene expression profile was observed between blastocysts developed in WOWs and blastocysts derived from group of 16 culture. To our knowledge, this is the first publication observing a large-scale change in the gene expression pattern related to microenvironmental properties. A total of 95 differential expressed transcripts were identified. Since the BlueChip compares 2000 transcripts these means $\sim 5 \%$ of all transcripts are differentially expressed among different treatments. Considering their molecular functions, blastocysts derived from WOW culture were found to be enriched with genes regulating ATP binding and reduced in oxidoreductase activity. The capacity of an embryo to produce ATP via oxidative phosphorylation is directly related to the oxygen consumption (Trimarchi et al. 2000) and oxygen consumption itself has been regarded as the best indicator of overall metabolic activity and a valuable parameter for evaluating embryo quality (Houghton et al. 1996, Trimarchi et al. 2000). Moreover, it is agreed that oxygen consumption is higher among embryos of superior morphological quality (Magnusson et al. 1986, Shiku et al. 2001), which has been confirmed involving both in vivo (Lopes et al. 2007) and in vitro produced embryos (Lopes et al. 2005) and leads to higher pregnancy rates (Trimarchi et al. 2000, Lopes et al. 2007). This showed embryos cultured in WOWs to be enriched with transcripts related to their further developmental potential. On the other hand, higher oxygen consumption by the embryos could also be a result of the increased accumulation and need for neutralization of reactive oxygen species (Harvey et al. 2002) indicating a less suitable microenvironment. However, culture of hemi-embryos at two-cell stage up to the blastocyst stage in the WOW system has shown high post-implantative developmental competence (Tagawa et al. 2008). Contrarily, blastocysts derived from WOW culture were found to be reduced with genes associated with metabolic activity. This is in accordance with a previous report in which increasing the distance between the embryos decreased their metabolic activity (Gopichandran \& Leese 2006). According to their biological process, genes associated with small molecule transport and signal transduction are also enriched in blastocysts derived from WOW environment. That would be accompanied by the accumulation of auto- and paracrine factors in the WOW system as proposed before (Thibodeaux et al. 1993, Stoddart et al. 1996, O'Neill 1997, Stoddart et al. 2001).

Blastocysts derived from WOW culture show higher expression of the CUL1 gene and a lower expression of the $T X N$ gene compared with bovine embryos cultured in group. High expression of CUL 1 could be an indicator for improved developmental competence because it has been shown to be associated with early embryonic death in murine (Wang et al. 1999, Dealy et al. 1999). In contrast to that, low expression of $T X N$ appears disadvantageous as observed in rats (Matsui et al. 1996). Considering other differentially expressed genes is controversial as well: contemplating genes downregulated in blastocysts derived from WOW culture, low expression of PTTG1 and KRT8 have been reported to be favourable for increased pregnancy rates and calf deliveries (El Sayed et al. 2006) whereas low expression of ALOXI5 and PLAC 8 has been reported to be associated with lower percentage of embryo implantation in the same report. In conclusion, although bovine blastocysts cultured in WOWs display a largely different gene expression pattern compared with embryos cultured in usual wells, it remains unclear whether these changes correlate with increased or decreased embryo quality.

Some of the genes that have been found to be differentially expressed are similar to other studies in which the BlueChip array has been used. For example in El-Sayed et al. (2006) KRT8 and PLAC8 were differentially enriched in biopsies from embryos resulted in resorption and in calf delivery respectively. However, since the use of the same cDNA array platform in different experiments can lead to the generation of similar candidates, the abundance of these genes at transcript level need to be interpreted carefully and therefore we compared blastocysts of different in vitro culture systems with in vivo derived ones by checking the relative transcript expression of five selected genes. All five genes showed an expression profile as it is observed in microarray analysis. Interestingly, the 
amount of transcript abundance was lowest in ex vivo flushed blastocysts for all genes analysed. Similar trends of expression were reported for other genes in embryos cultured in vitro compared with in Wrenzycki et al. (2001) and Lazzari et al. (2002). For ATP5A1 and PLAC8, gene expression level was the highest for group of 50 culture, followed by group of 16 culture, WOW culture and the lowest for vivo-flushed embryos. Therefore, expression of these two genes seems to be affected by embryo density as well as microenvironmental properties. On the other hand, the expression level of KRT8 was similar in blastocysts derived from group of 50 and group of 16 culture, but was clearly affected by the microenvironment of the WOW itself. Moreover, the expression of KRT8 was the lowest in embryos derived from vivo flushings, but not significantly different to blastocysts derived from WOW 16 culture system. Taken together, ATP5A1, PLAC8 and KRT8 expressions of in vivo derived bovine embryos were more similar to embryos derived from WOW culture indicating a high degree of normality. On the contrary, the expression of S100A10 and ZP3 genes was not affected by embryo density, but clearly influenced by WOW culture. The expression of these two genes in in vivo derived blastocysts was more different from WOW-derived blastocysts than from embryos cultured in group regardless of embryo density indicating a higher grade of artificiality of blastocysts derived from WOW culture.

Taken together, the WOW culture system provides a microenvironment for each individual embryo that compensates against the negative effects of low embryo densities. The WOWs increased the developmental rates of single bovine embryos to the blastocyst stage up to the level of embryos cultured in large groups with no differences in blastocyst quality in terms of differential cell counts and apoptosis level. Thus, this will provide benefit for single embryo culture allowing to produce single bovine IVP embryos of high medical and/or economical interest at high success rates. Moreover, we were able to show that the microenvironment beats the possibility to alter the embryonic gene expression profile in a dramatic manner. However, there is need for experiments comparing the post implantation developmental competence of bovine embryos derived from WOW culture and plain embryo culture to validate the benefit of the different gene expression profiles as well as to optimize WOW culture properties.

\section{Materials and Methods}

\section{Preparation of the WOW 16 culture dish}

Into the bottoms of the wells of a common five-well culture dish (Fa. Minitüb, Germany), we prepared WOWs by using standardized industrial borer of $0.7 \mathrm{~mm}$ diameter. A total of 16 small holes were produced in a $4 \times 4$ cluster in each well. Holes were like cylinders with a cylindrical bottom shape and
$0.7 \mathrm{~mm}$ deepness. Bored WOWs were cleaned by rinsing with tissue culture medium and air bubbles inside of the holes were flushed out with small glass pipettes under a stereomicroscope. Again wells were washed thrice with CR1 aa culture medium, which was already equilibrated at $39{ }^{\circ} \mathrm{C}$ and $5 \%(\mathrm{v} / \mathrm{v}) \mathrm{CO}_{2}$ in humidified air. Finally, all WOWs were overlaid with $500 \mu \mathrm{l}$ CR1 aa medium. Thus, each embryo was fixed in its own WOW, but all embryos were together harboured in one volume of culture medium.

\section{Preparation of IVF zygotes}

Bovine ovaries were obtained from a local slaughterhouse and brought into the laboratory in $30^{\circ} \mathrm{C}$ saline within $3 \mathrm{~h}$. Cumulus oocyte complexes (COCs) were aspirated from small follicles $(2-8 \mathrm{~mm})$ and COCs with a homogenous, evenly granulated ooplasm, surrounded by at least three layers of compact cumulus cells, were transferred to modified tissue culture medium (TCM199, Sigma) supplemented with 4.4 mM HEPES, $33.9 \mathrm{mM} \mathrm{NaCHO}$, $2 \mathrm{mM}$ pyruvate, $2.9 \mathrm{mM}$ calcium lactate, $55 \mu \mathrm{g} / \mathrm{ml}$ gentamicin and $12 \%(\mathrm{v} / \mathrm{v})$ heat-inactivated oestrus cow serum. After washing three times, COCs were cultured in groups of 50 in $400 \mu \mathrm{l}$ modified TCM supplemented with $10 \mu \mathrm{g} / \mathrm{ml} \mathrm{FSH}$ (FSH-p; Sheering, Kenilworth, NJ, USA) for $24 \mathrm{~h}$ at $39^{\circ} \mathrm{C}$ in a humidified atmosphere with $5 \%(\mathrm{v} / \mathrm{v}) \mathrm{CO}_{2}$ in air. Fertilization was performed in Fert-TALP medium (Parrish et al. 1988) supplemented with $20 \mu \mathrm{M}$ penicillinamine, $10 \mu \mathrm{M}$ hypotaurine, $2 \mu \mathrm{M}$ noradrenaline, $6 \mathrm{mg} / \mathrm{ml} \mathrm{BSA}, 50 \mu \mathrm{g} / \mathrm{ml}$ gentamicin and $1 \mu \mathrm{g} / \mathrm{ml}$ heparin. Final concentration of sperms in fertilization droplets was adjusted to $2 \times 10^{6} \mathrm{sperms} / \mathrm{ml}$. Eighteen hours after co-culture, the embryos were washed thrice from sperms and cumulus cells and were placed transferred to in vitro culture.

\section{In vitro culture of IVF embryos}

Embryo culture was performed in humidified atmosphere with $5 \%(\mathrm{v} / \mathrm{v}) \mathrm{CO}_{2}$ in air at $39^{\circ} \mathrm{C}$ for up to 8 days in $500 \mu \mathrm{l}$ CR1 aa culture medium (Rosenkrans \& First 1994) overlaid with mineral oil. Embryos were randomly allocated to three different culture systems: culture in the WOW 16 culture system (each embryo fixed in one WOW but all 16 embryos were within the same volume of culture medium leading to an embryo density of 1:32, Fig. 6A); in a group of 16 (Fig. 6B: 16 embryos in one volume of culture medium as a control for embryo density 1:32) and a group of 50 (Fig. 6C: 50 embryos in one volume of culture medium resulting in an embryo density of 1:10).
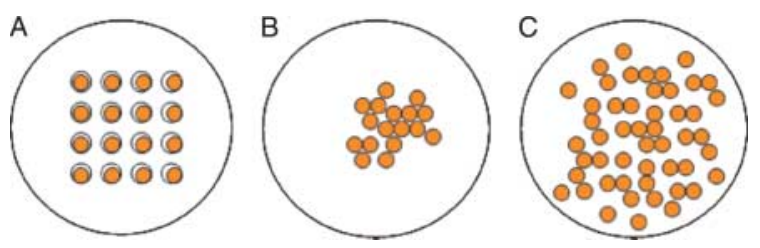

Figure 6 Schematic of the different experimental groups for in vitro culture of bovine embryos. The WOW 16 culture system harbours 16 embryos, each of them individually placed in one single WOW (A) group of 16 culture system (B) and group of 50 culture system (C). 


\section{Assessment of developmental competence}

Developmental competence was noted $48 \mathrm{~h}$ after placing the embryos into culture by counting the percentage of cleaved embryos and at day 8 by counting the number of embryos which reached blastocyst stage.

\section{Differential cell count of TE and ICM}

Differential cell counts were based on the immunological methods originally described previously (Handyside \& Hunter 1984). Briefly, the zona pellucida was removed by treatment with acid tyrode $(\mathrm{pH} 2.5)$. Zona-free blastocysts were then incubated in a 1:10 dilution of rabbit antibody (Sigma, D-9656) in PBS for $30 \mathrm{~min}$ at $29^{\circ} \mathrm{C}$. After washing in PBS, $+10 \%(\mathrm{v} / \mathrm{v})$ FCS blastocysts were incubated in a solution of complement (guinea pig complement, sigma, final dilution 1:10), propidium iodide (Sigma, $10 \mu \mathrm{g} / \mathrm{ml})$, FCS $(8 \%(\mathrm{v} / \mathrm{v}))$ in PBS for $30 \mathrm{~min}$ at $39^{\circ} \mathrm{C}$. Finally, the embryos were fixed in ice cold absolute ethanol with $19 \mu \mathrm{g} / \mathrm{ml}$ bisbenzimide stain (Hoechst 33258, Sigma B2883) for $20 \mathrm{~h}$ at $-20{ }^{\circ} \mathrm{C}$. Then, the embryos were transferred to a drop of glycerol on a glass slide and covered with a cover slip. Cell counting was done with a fluorescent microscope (Leika DM-IRB) with ICM cells appearing blue and TE cells appearing pink.

\section{Assessment of cellular apoptosis}

The TUNEL procedure was used to detect DNA fragmentation observed in late stages of apoptosis. Briefly, embryos were removed from culture medium (CR1 aa) and washed four times in $100 \mu \mathrm{l}$ drops of PBS (pH 7.4) containing $1 \mathrm{mg} / \mathrm{ml}$ PBS-PVP. Zona pellucida-intact embryos were fixed in a $100 \mu \mathrm{l}$ drop of $4 \%(\mathrm{w} / \mathrm{v})$ paraformaldehyde in PBS $(\mathrm{pH} 7.4)$ for $1 \mathrm{~h}$ at room temperature and washed twice in PBS-PVP. Embryos were then washed twice in PBS-PVP (2 min/wash) and permeabilized in $0.5 \%(\mathrm{v} / \mathrm{v})$ Triton X-100 containing $0.1 \%(\mathrm{w} / \mathrm{v})$ sodium citrate for $0,5 \mathrm{~h}$ at room temperature. After that embryos were washed in PBS-PVP and incubated with $50 \mu \mathrm{l}$ TUNEL reaction mixture (containing FITC-conjugated dUTP, and the enzyme terminal deoxynucleotidyl transferase) for $1 \mathrm{~h}$ at $37^{\circ} \mathrm{C}$ in the darkness. Labelling was observed using a Leika DM-IRB fluorescence microscope. Each embryo was analysed for the number of green/yellow fluorescent TUNEL-labelled nuclei indicating apoptotic cells. Finally, embryos were placed in PBS containing $5 \mu \mathrm{g} / \mathrm{ml}$ bisbenzimide stain (Hoechst 33258, Sigma B2883) for $5 \mathrm{~min}$ and were transferred on a glass slide covered with a cover slip. Total cell counting was done with a fluorescent microscope (Leika DM-IRB) with nuclei appearing blue.

\section{Embryo collection and freezing}

To collect in vivo derived blastocysts, Simmental heifers housed under identical conditions and of a similar age (2024 months) were synchronized by injection of PGF2 $\alpha$ twice (11 days between) followed by superovulation (Stimufol, Ulg FMV, Belgium) starting at day 11 after onset of oestrus. Flushings were performed as usual at day 7 post artificial insemination with D-PBS. Flushed in vivo derived blastocysts as well as blastocysts derived from in vitro culture were used for real-time PCR analyses. Blastocysts were washed twice in PBS and snap frozen in cryotubes, in groups containing a minimum of 10 embryos, containing minimal amounts of lysis buffer (0.8\% Igepal (Sigma), $40 \mathrm{U} / \mathrm{ml}$ RNasin (Promega), $5 \mathrm{mM}$ dithiothreitol (DTT; Promega)). All frozen embryos were stored at $-80{ }^{\circ} \mathrm{C}$ until used for RNA isolation.

\section{RNA isolation}

Messenger RNA isolation of blastocysts was performed at different points during the whole experiment. 1) A total of six pools, each containing 20 blastocysts from WOW 16 and group of 16, were used for array analysis after amplification, 2) a total of three pools, each containing five blastocysts derived from WOW 16 culture system, group of 16 culture, group of 50 culture system and ex vivo (gold standard) was used for real-time validation of array results. In all cases, mRNA was isolated using Dynabead oligo (dT)25 (Dynal Biotech, Oslo, Norway) according to the manufacturer's instructions. Briefly, oocytes in lysis buffer were mixed with $40 \mu \mathrm{l}$ binding buffer (20 mM Tris- $\mathrm{HCl}$ (pH 7.5), $1 \mathrm{M} \mathrm{LiCl}$ and 2 mM EDTA (pH 8.0)) and incubated at $70{ }^{\circ} \mathrm{C}$ for $5 \mathrm{~min}$ to obtain complete lysis of the oocytes and to release RNA. Ten microlitres of oligo (dT)25 attached magnetic bead suspension was added to the samples, and incubated at room temperature for $30 \mathrm{~min}$. The hybridized mRNA and magnetic beads were washed thrice using washing buffer (10 mM Tris-HCL (pH 7.5), $0.15 \mathrm{mM} \mathrm{LiCl}$ and $1 \mathrm{mM}$ EDTA ( $\mathrm{pH}$ 8.0)). For each sample, cDNA synthesis has been performed using oligo (dT)23 primer and superscript reverse transcriptase II (Invitrogen) except for samples used in array analysis where the RT was performed using T7 promotorattached oligo $\mathrm{d}(\mathrm{T}) 21$ primer.

\section{RNA amplification}

First- and second-strand cDNA syntheses were carried out as described in our previous studies (El Sayed et al. 2006). Briefly, $1 \mu \mathrm{l}$ of $20 \mu \mathrm{M}$ T7 oligo $\mathrm{d}(\mathrm{T}) 21$ primer (TCTAGTC GACGGCCAGTGAATTGTAATACGACTCACTATAGG-GCG(T)21) was added to mRNA of the oocytes and co-incubated for $5 \mathrm{~min}$ at $70{ }^{\circ} \mathrm{C}$ and placed immediately on ice for $3 \mathrm{~min}$. To this, $8 \mu \mathrm{RT}$ reaction mix $(1 \times$ first-strand buffer, $0.3 \mathrm{mM} d N T P, 0.1 \mathrm{mM}$ DTT, $10 \mathrm{U}$ of RNase inhibitor (Promega) and $200 \mathrm{U}$ of Superscript II RT (Invitrogen)) were added to $11 \mu \mathrm{l} \mathrm{mRNA}$ sample. The reaction was incubated at $42{ }^{\circ} \mathrm{C}$ for $90 \mathrm{~min}$ and terminated at $75^{\circ} \mathrm{C}$ for $15 \mathrm{~min}$. Second-strand synthesis and global PCR amplification were carried out using degenerated oligonucleotides primer (DOP) and PCR master kit (Roche Diagnosis). For this, $20 \mu \mathrm{l}$ first-strand cDNA product, $40 \mu \mathrm{l}$ $2 \times$ DOP PCR master mix, $1 \mu$ l DOP primer to the final concentration, $1 \mu \mathrm{l} 20 \mu \mathrm{M}$ T7 oligo (dT)21 primer and $16 \mu \mathrm{l}$ water were added and properly mixed. This PCR was heated at $95{ }^{\circ} \mathrm{C}$ for $5 \mathrm{~min}$ to denature the sample and to activate the polymerase, followed by cycle of denaturation at $95{ }^{\circ} \mathrm{C}$ for $30 \mathrm{~s}$ and annealing at $30{ }^{\circ} \mathrm{C}$ for $90 \mathrm{~s}$. Unspecific primer annealing was achieved through application of relatively low annealing temperature. Subsequently, the temperature was increased at the rate of $0.2{ }^{\circ} \mathrm{C} / \mathrm{s}$ until it reached $72{ }^{\circ} \mathrm{C}$ and incubated for 
3 min at this temperature. To this, second-strand synthesis was completed and the global PCR amplification was continued for the rest of 10 cycles at $94{ }^{\circ} \mathrm{C}$ for $30 \mathrm{~s}, 60{ }^{\circ} \mathrm{C}$ for $30 \mathrm{~s}, 72{ }^{\circ} \mathrm{C}$ for $3 \mathrm{~min}$ and final extension at $72{ }^{\circ} \mathrm{C}$ for $7 \mathrm{~min}$. The amplification of RNA using 10 cycles was used in a study done in our laboratory (Mamo et al. 2006) and it showed no effect on the representativeness of the original mRNA population after in vitro transcription. The cDNA was purified and used for in vitro transcription using AmpliScribe T7 transcription kit (Epicentre technologies, Oldendorf, Germany) according to the manufacturer's instruction. Briefly, $2 \mu \mathrm{l}$ of $10 \times$ reaction buffer, $4 \mu \mathrm{l}$ dNTP $(100 \mathrm{mM}$ each of ATP, CTP, GTP and UTP), $2 \mu \mathrm{l}$ DTT and $2 \mu \mathrm{l}$ T7 RNA polymerase were added to $10 \mu \mathrm{l}$ of purified cDNA, mixed well and incubated at $42{ }^{\circ} \mathrm{C}$ for $3 \mathrm{~h}$. At the end of incubation, $1 \mu \mathrm{l}$ DNase has been added and incubated at $37^{\circ} \mathrm{C}$ for $30 \mathrm{~min}$. Then, the amplified RNA (aRNA) was purified using RNeasy Mini kit (Qiagen) according to the manufacturer's recommendations. Finally, the aRNA was eluted in $30 \mu \mathrm{l}$ RNase-free water from which $8 \mu \mathrm{l}$ was taken to estimate the yield, integrity, purity of aRNA by gel electrophoresis and u.v. absorbance reading at A260/ 280 using Ultrospec 2100 pro u.v./Visible Spectrophotometer (Amersham Bioscience).

\section{Aminoallyl indirect labelling and dye coupling}

Minimum Information About Microarray Experiments guidelines were adhered to in our experimental design. Three independent labelling reactions (including dye swaps, Cy3 and Cy5) were carried out per aRNA sample pertaining to each biological replicate. Accordingly, $3 \mu \mathrm{g}$ aRNA from each blastocyst pool was used as template in RT reactions incorporating amino-modified dUTPs into the cDNA using the CyScribe Post-Labelling Kit (Amersham Biosciences). The aRNA, anchored oligo(dT) and random nanomer primers were co-incubated at $70{ }^{\circ} \mathrm{C}$ for $5 \mathrm{~min}$ followed by $10 \mathrm{~min}$ incubation at room temperature. Then $10 \mu \mathrm{l}$ reaction mix (containing $4 \mu \mathrm{l}$ of $5 \times$ first-strand buffer, $2 \mu \mathrm{l}$ of $0.1 \mathrm{M}$ DTT, $1.5 \mu \mathrm{l}$ dNTP mix, $1.5 \mu \mathrm{l}$ aminoallyl dUTP and $1 \mu \mathrm{l}$ CyScript reverse transcriptase) was added and incubated at $42{ }^{\circ} \mathrm{C}$ for $90 \mathrm{~min}$. At the end of this reaction, $2 \mu \mathrm{l}$ of $2.5 \mathrm{M} \mathrm{NaOH}$ was added to hydrolyse any rest of mRNA and incubated at $37^{\circ} \mathrm{C}$ for $15 \mathrm{~min}$. The aminoallyl-labelled cDNA samples were purified using CyScribe GFX Purification kit (Amersham Biosciences) after adding $10 \mu \mathrm{l}$ of $2 \mathrm{M}$ HEPES. The purified aminoallyl-labelled cDNA was then eluted in $60 \mu \mathrm{l} 0.1 \mathrm{M}$ sodium bicarbonate. The cDNA sample were differentially labelled indirectly using N-hydroxysuccinate-derived Cy3 and Cy 5 dyes and incubated for $1.5 \mathrm{~h}$ at room temperature in darkness. At the end of incubation, non-reacting dyes were quenched by adding $15 \mu \mathrm{l}$ of $4 \mathrm{M}$ hydroxylamine solution (Sigma) and incubated for $15 \mathrm{~min}$ at room temperature in darkness. To avoid variation due to dye coupling, aRNA samples from the same group were labelled reversibly either with Cy3 or Cy5 for dye swaps hybridizations. The reaction was then purified with CyScribe GFX Purification kit (Amersham Biosciences). Samples were finally eluted in $60 \mu$ l elution buffer.

\section{Probe hybridization}

Pre-hybridization of the slides was performed by placing the array slides (BlueChip; Prof. Sirard, University of Laval, Québec, Canada) into a corning GAPS II slide container and incubating in warmed $\left(55^{\circ} \mathrm{C}\right)$ pre-hybridization buffer $(5 \times \mathrm{SSC}$, $0.1 \%$ SDS (Sigma) and 1\% BSA (Roche Diagnostic)) for $20 \mathrm{~min}$. Following pre-hybridization, slides were rinsed for $1 \mathrm{~min}$ in boiling RNA-free water to denature probes and to wash unbound cDNA from the slide surface. Immediately, the slides were immersed in RNA-free water at room temperature then isopropanol for $1 \mathrm{~min}$ each. Then the slides were dried by centrifugation at $\geq 3000 \mathrm{~g}$ for $2 \mathrm{~min}$.

Hybridization and post-hybridization washes were carried out as described previously (Hedge et al. 2000). Samples that were going to be hybridized on a specific array were mixed and dried in a speedvac (SPD111v-230) centrifuge (Savant, Holbrook, NY, USA), then the pellet was re-suspended in prewarmed $\left(42{ }^{\circ} \mathrm{C}\right)$ formamide-based hybridization buffer $(15 \mu \mathrm{l}$ hybridization buffer (Amersham Bioscience), $30 \mu \mathrm{l} 100 \%$ formamide and $15 \mu \mathrm{l}$ DEPC water). To this, $2.5 \mu$ l yeast tRNA $(4 \mathrm{mg} / \mathrm{ml})$ and $2.5 \mu \mathrm{l}$ Cot-human DNA ( $1 \mathrm{mg} / \mathrm{ml}$; Invitrogen) were added to avoid non-specific hybridization. The pellet was denatured at $95{ }^{\circ} \mathrm{C}$ for $5 \mathrm{~min}$, centrifuged briefly and hybridized to the array. The arrays were covered with glass cover slips (Roth, Karlsruhe, Germany) and placed and fixed well in the hybridization cassette (TeleChem International Inc., Sunnyvale, CA, USA). The cassette was incubated in a hybridization chamber (GFL, Dülmen, Germany) at $42{ }^{\circ} \mathrm{C}$ for $16-20 \mathrm{~h}$. After hybridization, slides were washed twice with $2 \times \mathrm{SSC}-0.1 \%$ SDS buffer for $5 \mathrm{~min}$ at $42{ }^{\circ} \mathrm{C}$, then once with $1 \times \mathrm{SSC}, 0.2 \times \mathrm{SSC}$ and $0.1 \times \mathrm{SSC}$ for $5 \mathrm{~min}$ each at room temperature. Finally, the slides were rinsed in RNA-free water, then into isopropanol for one min each and centrifuged at $\geq 3000 \mathrm{~g}$ for $2 \mathrm{~min}$.

\section{Array scanning and data analysis}

The slides were scanned using Axon GenePix 4000B scanner (Axon Instruments, Foster City, CA, USA). The GenePix Pro 4.0 software (Axon Instruments) was used to process the images, find spots, integrate robot-spotting files and finally to create reports of spot intensity data. The LOWESS normalization of microarray data was performed using GPRocessor 2.0a software (http:// bioinformatics.med.yale.edu/group). The normalized data were used to calculate intensity ratios of all replicates and to obtain one value per clone. Ratios were finally $\log _{2}$ transformed and submitted to SAM analysis. Microarray data analysis was performed using SAM, a free software developed at Stanford University (http://www-stat.stanford.edu/ tibs/SAM/). Hierarchical clustering and heatmap of $\log _{2}$-transformed data for up- and downregulated genes were generated using PermutMatrix (version 1.8.2) available at (http://www.lirmm.fr/ $\%$ 7Ecaraux/PermutMatrix/). Genes expressed equally in both samples were not included in the hierarchical clustering.

\section{Quantitative real-time PCR analysis}

To validate microarray results, five genes were selected based on their relevance to bovine embryo development for further 
Table 3 Selected primer sequences for real-time RT-PCR.

\begin{tabular}{|c|c|c|c|}
\hline Gene name & GenBank accession number & Primer sequences & Product size (bp) \\
\hline ATP5A1 & NM_174684 & $\begin{array}{l}\text { F: 5'-CTCTTGAGTCGTGGTGTGCG-3' } \\
\text { R: 5'-CCTGATGTTGGCTGATAACGTG-3' }\end{array}$ & 184 \\
\hline PLAC8 & NM_016619 & $\begin{array}{l}\text { F: 5'-CGGTGTTCCAGAGGTTTTTCC-3' } \\
\text { R: } 5^{\prime} \text {-ACTGACCGTCTGACCGTAGAA-3' }\end{array}$ & 163 \\
\hline KRT8 & X12877 & $\begin{array}{l}\text { F: 5'-CACCAGTTCCAAGCCTGTGG-3' } \\
\text { R: } 5^{\prime} \text {-TCAGGTCTCCTGTGCAGATGC-3' }\end{array}$ & 176 \\
\hline S100A10 & NM174681 & $\begin{array}{l}\text { F: 5'-GGATTTCTGAGCATATGGGACC -3' } \\
\text { R: 5'-GAGCAAGAGGATGCAAGCAATA -3' }\end{array}$ & 131 \\
\hline$Z P 3$ & NM_173974 & $\begin{array}{l}\text { F: 5'-CCACCTGTTGGAGGACTTGC-3' } \\
\text { R: 5'-TCTCACCGATGCCTCCTCTG-3' }\end{array}$ & 161 \\
\hline GAPDH & BC102589 & $\begin{array}{l}\text { F: 5'-ACCCAGAAGACTGTGGATGG-3' } \\
\text { R: 5'-ACGCCTGCTTCACCACCTTC-3' }\end{array}$ & 247 \\
\hline
\end{tabular}

analysis by real-time PCR (Table 3). Quantitative analysis of cDNA samples was performed using ABI PRISM 7000 sequence detection system (Applied Biosystems, Foster City, CA, USA). The cDNA synthesized from all blastocyst samples were subjected to real-time PCR using GAPDH primer to test for any variation in the expression of this internal control gene as it has been used previously in studies of ours (Ghanem et al. 2007) and others (Misirlioglu et al. 2006). After confirming that there were no significant differences in the relative abundance of GAPDH between samples, all transcripts were quantified using independent real-time PCR runs. Standard curves were generated for both the target and the endogenous control genes using serial dilution of plasmid DNA $\left(10^{1}-10^{8}\right.$ molecules). The PCR was performed in $20 \mu \mathrm{l}$ reaction volume containing $9 \mu \mathrm{l}$ of $2.5 \times$ RealMasterMix/20× SYBR (Eppendorf, Hamburg, Germany). During each PCR, samples from the same cDNA source were run in duplicate to control the reproducibility of real-time results. A universal thermal cycling parameter $10 \mathrm{~s}$ at $50{ }^{\circ} \mathrm{C}, 10 \mathrm{~min}$ at $95^{\circ} \mathrm{C}, 15 \mathrm{~s}$ at $95^{\circ} \mathrm{C}$ for 45 cycles and $60 \mathrm{~s}$ at $60{ }^{\circ} \mathrm{C}$ ) was used to quantify each gene of interest. After the end of the last cycle, dissociation curve was generated by starting the fluorescence acquisition at $60{ }^{\circ} \mathrm{C}$ and taking measurements every 7 -sec interval until the temperature reached $95^{\circ} \mathrm{C}$. Final quantitative analysis was done using the relative standard curve method and results were reported as the relative expression or $\mathrm{n}$-fold difference to the calibrator after normalization of the transcript amount relative to the endogenous control (Tesfaye et al. 2004).

\section{Experimental design}

Experiment 1. Effect of microenvironment on in vitro developmental characteristics of bovine zygotes

IVF-derived zygotes were randomly allocated into three culture groups: WOW 16 culture, group of 16 culture and group of 50 culture. While embryos cultured in the groups of 16 (effect of microenvironment) and 50 (total embryo density) served as controls, subsequent developmental characteristics in terms of development to the blastocyst stage and differential cell counts were analysed. Moreover, additional blastocysts of each group were produced and the corresponding apoptotic cell index was determined.
Experiment 2. Effect of microenvironment and embryo density on embryonic gene expression profile

Day-8 blastocysts derived from WOW 16 culture and group of 16 culture system were compared by BlueChip array to identify differential expressed genes of these embryos.

Experiment 3. Comparison of in vivo derived bovine blastocysts with ones derived from different vitro culture systems in terms of gene expression

The expression level of five selected genes were compared between day-8 blastocysts derived from WOW 16 culture system, group of 16, group of 50 culture system and vivo-flushed blastocysts (gold standard) by performing real-time RT-PCR.

\section{Statistical analysis}

The data for this study were analysed using the Statistical Analysis System (SAS) version 8.0 (SAS Institute Inc., Cary, NC, USA) software package. Developmental rates of in vitro produced embryos were analysed by $\chi^{2}$-test. Differences of $P<0.05$ were considered to be significant. Array data analysis was performed with the SAM software program developed at Stanford University (http://www-stat.stanford.edu/ tibs/SAM). Gene expression levels in day-8 blastocysts are expressed as folds, with in vitro produced embryos derived from group of 16 culture set to 1.0. The mRNA expression analysis for studied genes was performed based on the standard curve method. The relative expression data were analysed using general linear model (GLM) of the SAS software package version 8.0 (SAS Institute Inc). Differences in mean values were tested using ANOVA followed by a multiple pair wise comparison using $t$-test. Differences of $P<0.05$ were considered to be significant.

\section{Declaration of interest}

We declare there is no conflict of interest that could affect the impartiality of the research reported.

\section{Funding}

This research did not receive any specific grant from any funding agency in the public, commercial or not-for-profit sector. 


\section{Acknowledgements}

We are grateful to Prof. Sirard from Universtiy of Laval, Canada, for provision of BlueChip bovine cDNA array. Moreover, we thank Mr Stefan Knauf, University of Bonn, Germany for preparation of WOWs of different calibres.

\section{References}

Blondin P \& Sirard MA 1995 Oocyte and follicular morphology as determining characteristics for developmental competence in bovine oocytes. Molecular Reproduction and Development 41 54-62.

Brison DR \& Schultz RM 1997 Apoptosis during mouse blastocyst formation: evidence for a role for survival factors including transforming growth factor alpha. Biology of Reproduction 56 1088-1096.

Carolan C, Lonergan P, Khatir H \& Mermillod P 1996 In vitro production of bovine embryos using individual oocytes. Molecular Reproduction and Development 45 145-150.

Dealy MJ, Nguyen KV, Lo J, Gstaiger M, Krek W, Elson D, Arbeit J, Kipreos ET \& Johnson RS 1999 Loss of CUL1 results in early embryonic lethality and dysregulation of cyclin E. Nature Genetics 23 245-248.

Ferry L, Mermillod P, Massip A \& Dessy F 1994 Bovine embryos cultured in serum-poor oviduct-conditioned medium need cooperation to reach the blastocyst stage. Theriogenology 42 445-453.

Fouladi-Nashta AA, Alberio R, Kafi M, Nicholas B, Campbell KH \& Webb R 2005 Differential staining combined with TUNEL labelling to detect apoptosis in preimplantation bovine embryos. Reproductive Biomedicine Online 10 497-502.

Fujita T, Umeki H, Shimura H, Kugumiya K \& Shiga K 2006 Effect of group culture and embryo-culture conditioned medium on development of bovine embryos. Journal of Reproduction and Development $\mathbf{5 2}$ 137-142.

Fukui Y, Lee ES \& Araki N 1996 Effect of medium renewal during culture in two different culture systems on development to blastocysts from in vitro produced early bovine embryos. Journal of Animal Science $\mathbf{7 4}$ 2752-2758.

Gardner DK \& Lane M 1993 Amino acids and ammonium regulate mouse embryo development in culture. Biology of Reproduction 48 377-385.

Ghanem N, Hoelker M, Rings F, Jennen D, Tholen E, Sirard MA, Torner M, Kanitz W, Schellander K \& Tesfaye D 2007 Alterations in transcript abundance of bovine oocytes recovered at growth and dominance phases of the first follicular wave. BMC Developmental Biology 27 90-119.

Gopichandran N \& Leese HJ 2006 The effect of paracrine/autocrine interactions on the in vitro culture of bovine preimplantation embryos. Reproduction 131 269-277.

Handyside AH \& Hunter S 1984 A rapid procedure for visualising the inner cell mass and trophectoderm nuclei of mouse blastocysts in situ using polynucleotide-specific fluorochromes. Journal of Experimental Zoology 231 429-434.

Harlow GM \& Quinn P 1982 Development of preimplantation mouse embryos in vivo and in vitro. Australian Journal of Science 35 187-193.

Harvey AJ, Kind KL \& Thompson JG 2002 REDOX regulation of early embryo development. Reproduction 123 479-486.

Hazeleger NL, Hill DJ, Stubbing RB \& Walton JS 1995 Relationship of morphology and follicular fluid environment of bovine oocytes to their developmental potential in vitro. Theriogenology 43 509-522.

Hegde P, Qi R, Abernathy K, Gay C, Dharap S, Gaspard R, Hughes JE, Snesrud E, Lee N \& Quackenbush J 2000 A concise guide to cDNA microarray analysis. BioTechniques 29 548-556.

Hill JA 2001 Maternal-embryonic cross-talk. Annals of the New York Academy of Sciences 943 17-25.

Hoelker M, Schmoll F, Schneider H, Rings F, Gilles M, Tesfaye D, Jennen D, Tholen E, Griese J \& Schellander K 2006 Bovine blastocyst diameter as a morphological tool to predict embryo cell counts, embryo sex, hatching ability and developmental characteristics after transfer to recipients. Reproduction, Fertility, and Development 18 551-557.

Houghton FD, Thompson JG, Kennedy CJ \& Leese HJ 1996 Oxygen consumption and energy metabolism of the early mouse embryo. Molecular Reproduction and Development 44 476-485.
Johnson MH \& Nasr-Esfahani MH 1994 Radical solutions and cultural problems: could free oxygen radicals be responsible for the impaired development of preimplantation mammalian embryos in vitro? BioEssays 16 31-38.

Kato Y \& Tsunoda Y 1994 Effects of the culture density of mouse zygotes on the development in vitro and in vivo. Theriogenology 41 1315-1322.

Khurana NK \& Niemann H 2000 Effects of oocyte quality, oxygen tension, embryo density, cumulus cells and energy substrates on cleavage and morula/blastocyst formation of bovine embryos. Theriogenology $\mathbf{5 4}$ $741-756$.

Lane M \& Gardner DK 1992 Effect of incubation volume and embryo density on the development and viability of mouse embryos in vitro. Human Reproduction 7 558-562.

Larson MA \& Kubisch HM 1999 The effects of group size on development and interferon-tau secretion by in-vitro fertilized and cultured bovine blastocysts. Human Reproduction 14 2075-2079.

Lazzari G, Wrenzycki C, Herrmann D, Duchi R, Kruip T, Niemann H \& Galli C 2002 Cellular and molecular deviations in bovine in vitroproduced embryos are related to the large offspring syndrome. Biology of Reproduction 67 767-775.

Lopes AS, Larsen LH, Ramsing N, Lovendahl P, Raty M, Peippo J, Greve T \& Callesen H 2005 Respiration rates of individual bovine in vitro-produced embryos measured with a novel, non-invasive and highly sensitive microsensor system. Reproduction 130 669-679.

Lopes AS, Madsen SE, Ramsing NB, Lovendahl P, Greve T \& Callesen H 2007 Investigation of respiration of individual bovine embryos produced in vivo and in vitro and correlation with viability following transfer. Human Reproduction 22 558-566.

Magnusson C, Hillensjo T, Hamberger L \& Nilsson L 1986 Oxygen consumption by human oocytes and blastocysts grown in vitro. Human Reproduction 1 183-184.

Mamo S, Sargent CA, Affara NA, Tesfaye D, El-Halawany N, Wimmers K, Gilles M, Schellander K \& Ponsuksili S 2006 Transcript profiles of some developmentally important genes detected in bovine oocytes and in vitro-produced blastocysts using RNA amplification and cDNA microarrays. Reproduction in Domestic Animals 41 527-534.

Matsui M, Oshima M, Oshima H, Takaku K, Maruyama T, Yodoi J \& Taketo MM 1996 Early embryonic lethality caused by targeted disruption of the mouse thioredoxin gene. Developments in Biologicals 178 179-185.

Misirlioglu M, Page GP, Sagirkaya H, Kaya A, Parrish JJ, First NL \& Memili E 2006 Dynamics of global transcriptome in bovine matured oocytes and preimplantation embryos. PNAS 103 18905-18910.

Moessner J \& Dodson WC 1995 The quality of human embryo growth is improved when embryos are cultured in groups rather than separately. Fertility and Sterility 64 1034-1035.

Nagao Y, lijima R \& Saeki K 2008 Interaction between embryos and culture conditions during in vitro development of bovine early embryos. Zygote 16 127-133.

Niemann H \& Wrenzycki C 2000 Alterations of expression of developmentally important genes in preimplantation bovine embryos by in vitro culture conditions: implications for subsequent development. Theriogenology 53 21-34.

O'Doherty EM, Wade MG, Hill JL \& Boland MP 1997 Effects of culturing bovine oocytes either singly or in groups on development to blastocysts. Theriogenology 48 161-169.

de Oliveira AT, Lopes RF \& Rodrigues JL 2005 Gene expression and developmental competence of bovine embryos produced in vitro under varying embryo density conditions. Theriogenology 64 1559-1572.

O'Neill C 1997 Evidence for the requirement of autocrine growth factors for development of mouse preimplantation embryos in vitro. Biology of Reproduction 56 229-237.

Palasz AT \& Thundathil J 1998 The effect of volume of culture medium and embryo density on in vitro development of bovine embryos. Theriogenology 49212.

Paria BC \& Dey SK 1990 Preimplantation embryo development in vitro: cooperative interactions among embryos and role of growth factors. PNAS 87 4756-4760.

Parrish JJ, Susko-Parrish J, Winer MA \& First NL 1988 Capacitation of bovine sperm by heparin. Biology of Reproduction 38 1171-1180. 
Rosenkrans CF Jr \& First NL 1994 Effect of free amino acids and vitamins on cleavage and developmental rate of bovine zygotes in vitro. Journal of Animal Science 72 434-437.

El Sayed A, Hoelker M, Rings F, Salilew D, Jennen D, Tholen E, Sirard MA, Schellander K \& Tesfaye D 2006 Large-scale transcriptional analysis of bovine embryo biopsies in relation to pregnancy success after transfer to recipients. Physiological Genomics 28 84-96.

Schultz GA \& Heyner S 1993 Growth factors in preimplantation mammalian embryos. Oxford Reviews of Reproductive Biology 15 43-81.

Shiku H, Shiraishi T, Ohya H, Matsue T, Abe H, Hoshi H \& Kobayashi M 2001 Oxygen consumption of single bovine embryos probed by scanning electrochemical microscopy. Analytical Chemistry $\mathbf{7 3}$ 3751-3758.

Sinclair KD, Dunne LD, Maxfield EK, Maltin CA, Young LE, Wilmut I, Robinson J \& Broadbent PJ 1998 Fetal growth and development following temporary exposure of day 3 ovine embryos to an advanced uterine environment. Reproduction, Fertility, and Development 10 263-269.

Stoddart NR, Wild AE \& Fleming TP 1996 Stimulation of development in vitro by platelet-activating factor receptor ligands released by mouse preimplantation embryos. Journal of Reproduction and Fertility 108 47-53.

Stoddart NR, Roudebush WE \& Fleming SD 2001 Exogenous plateletactivating factor stimulates cell proliferation in mouse pre-implantation embryos prior to the fourth cell cycle and shows isoform-specific stimulatory effects. Zygote 9 261-268.

Tagawa M, Matoba S, Narita M, Saito N, Nagai T \& Imai K 2008 Production of monozygotic twin calves using the blastomere separation technique and Well of the Well culture system. Theriogenology 69 574-582.

Taka M, Iwayama H \& Fukui Y 2005 Effect of the Well of the Well (WOW) system on in vitro culture for porcine embryos after intracytoplasmic sperm injection. Journal of Reproduction and Development 51 533-537.

Tesfaye D, Ponsuksili S, Wimmers K, Gilles M \& Schellander K 2004 A comparative expression analysis of gene transcripts in post-fertilization developmental stages of bovine embryos produced in vitro or in vivo. Reproduction in Domestic Animals 39 396-404.
Thibodeaux JK, Del Vecchio RP \& Hansel W 1993 Role of plateletderived growth factor in development of in vitro matured and in vitro fertilized bovine embryos. Journal of Reproduction and Fertility 98 $61-66$.

Thouas GA, Jones GM \& Trounson AO 2003 The 'GO' system - a novel method of microculture for in vitro development of mouse zygotes to the blastocyst stage. Reproduction 126 161-169.

Trimarchi JR, Liu L, Porterfield DM, Smith PJ \& Keefe DL 2000 Oxidative phosphorylation-dependent and -independent oxygen consumption by individual preimplantation mouse embryos. Biology of Reproduction 62 1866-1874.

Vajta G, Peura TT, Holm P, Paldi A, Greve T, Trounson AO \& Callesen H 2000 New method for culture of zona-included or zona-free embryos: the Well of the Well (WOW) system. Molecular Reproduction and Development 55 256-264.

Vajta G, Korösi T, Du Y, Nakata K, leda S, Kuwayama M \& Nagy ZP 2008 The Well-of-the-Well system: an efficient approach to improve embryo development. Reproductive Biomedicine Online 17 73-81.

Wang Y, Penfold S, Tang X, Hattori N, Riley P, Harper JW, Cross JC \& Tyers M 1999 Deletion of the CUL1 gene in mice causes arrest in early embryogenesis and accumulation of cyclin E. Current Biology 9 1191-1194.

Wrenzycki C, Herrmann D, Carnwath JW \& Niemann H 1998 Expression of RNA from developmentally important genes in preimplantation bovine embryos produced in TCM supplemented with BSA. Journal of Reproduction and Fertility 112 387-398.

Wrenzycki C, Herrmann D, Keskintepe L, Martins A Jr, Sirisathien S, Brackett B \& Niemann H 2001 Effects of culture system and protein supplementation on mRNA expression in pre-implantation bovine embryos. Human Reproduction 16 893-901.

Received 27 August 2008

First decision 8 October 2008

Revised manuscript received 8 December 2008

Accepted 19 December 2008 